\title{
Collaborative Kaitiakitanga - New Joint Pathways in Guardianship
}

\author{
Vasiti Palavi ${ }^{\ddagger}$, Nicola Railton ${ }^{\ddagger}$, Sheridan Waitai§ \\ ‡ Tāmaki Paenga Hira Auckland Museum, Auckland, New Zealand \\ § Ngāti Kurī Trust Board, Kaitaia, New Zealand
}

Corresponding author: Vasiti Palavi (vpalavi@aucklandmuseum.com)

Received: 25 May 2018| Published: 15 Jun 2018

Citation: Palavi V, Railton N, Waitai S (2018) Collaborative Kaitiakitanga - New Joint Pathways in Guardianship. Biodiversity Information Science and Standards 2: e26954. https://doi.org/10.3897/biss.2.26954

\section{Abstract}

Ehara taku toa i te toa takitahi Engari, he toa takitini - Success is not the work of one, but the strength of many.

This metaphor encapsulates the collaborative sharing of knowledge, collections and aspirations held by communities and Museums to create new, mutually beneficial research pathway and community outcomes for all.

Ngāti Kurī is descended from the founding people of the northernmost peninsula of Aotearoa - Te Hiku o Te Ika. The mana and rangatiratanga of Ngāti Kurī extends into a number of ecological biogeographically significant sites on the whenua (the land) and moana (sea) - Rangitāhua (Kermadec Islands) an international marine reserve, Manawatawhi (Three Kings Islands) a nature reserve and Te Hiku o Te Ika (mainland) including Kapowairua. There are many unique species that have been found within their rohe (territorial lands) and are important centres of endemism. Ngāti Kurī settled their treaty claim in 2014 and was a key claimant in Waitangi Tribunal claim no. 262 (WAI 262) relating to Maori intellectual property rights particularly relating to flora and fauna. $\mathrm{Ngāti}$ Kurī aim to reclaim, restore (knowledge and practises), revitalise and rejuvenate themselves and the environments they have inherited in the sea and on land.

To realise this vision Ngāti Kurī partnered with a number of scientific partners on a "Pupuri Mauhanga o Ngāti Kurī " (species stocktake/inventory).The key objective of this project 
being to strengthen their kaitiakitanga - build community resilience, capacity and capability which are aligned to WAI 262 and integrated into their strategic vision - Ara Whanui (Many pathways) and Te Haumihi (ecological restoration plan) for their rohe. The resulting species lists will form the baseline data to develop strategies and tactics for the management and rejuvenation of taonga (treasured) species in their rohe.

In March 2018 Ngāti Kurī partnered with Tāmaki Paenga Hira Auckland Museum to undertake a BioBlitz (https://www.landcareresearch.co.nz/science/plants-animals-fungi/ bioblitz) in their rohe (territorial lands). This was part of a larger programme of work documenting biodiversity combining both scientific and Mātauranga (Maori indigenous knowledge system) approaches. This unique model aims to empower intergenerational engagement and partnership with science in the natural environment, centred around tamariki (children) and instilling the responsibility of kaitiakitanga (guardianship). The results have been highly successful through this internationally significant approach. This approach will be described with highlights of the BioBlitz and larger biodiversity programme as an example of a successful bicultural relationship.

\section{Keywords}

bicultural, BioBlitz, Ngāti Kurī Kapowairua, Auckland Museum, Tāmaki Paenga Hira, Pupuri mauhanga, Te Haumihi, Arawhanui, WAI 262

\section{Presenting author}

Vāsiti Palavi ${ }^{1}$, Nicola Railton ${ }^{2}$ and Sheridan Waitai ${ }^{3}$

${ }^{1}$ Senior Collection Manager- Natural Sciences, Tāmaki Paenga Hira Auckland War Memorial Museum

${ }^{2}$ Manager Māori Development, Tāmaki Paenga Hira Auckland War Memorial Museum

${ }^{3} \mathrm{Ngāti}$ Kuri Trust Board Member 